\title{
Driving Organizational Readiness for Change through Strategic Workshops
}

\author{
Johan Roos \\ Viktor O. Nilsson
}

\author{
HULT International Business School \\ London, Boston, San Francisco, Shanghai, Dubai
}

\begin{abstract}
Change initiatives in organizations often fail because people are neither committed to nor convinced they can implement the change successfully. The change challenge is a practical problem for most leaders. The vast literature on change management offers insights into obstacles to change and how to overcome them, and the emerging literature on readiness for change offers a plethora of instruments for how to assess it, though primarily in health care settings. However, there is limited advice about how to design workshops around new initiatives in organizations to increase readiness for change. To address this problem, we developed a model of the drivers of change readiness, based on survey data from 374 participants in 69 independently facilitated workshops to test hypotheses. The findings show which constructs have the most predictive power. These results have important implications for how to design and facilitate workshops that increase participants' readiness for change. The study makes several contributions to the theory and practice of creating shared readiness for change.
\end{abstract}

Keywords: change management, readiness for change, strategic workshops, structural equation modelling, LEGO® SERIOUS PLAY®

Received: 21 January 2019

ISSN 2056-757X

Revised: 7 February 2020

Accepted: 15 February 2020

https://doi.org/10.18646/2056.71.20-001 


\section{Change is the new normal, yet we still struggle to deal with it}

Many managers rightfully worry about developing and implementing change initiatives. If people do not want to change, for whatever reason, any initiative will likely fail. But we also know that if the people involved can co-create the foundation for change and believe they can implement what needs to be done, they are more likely to cooperate, contribute, collaborate, and deal with any emerging problems along the way. The result is a more effective, efficient, and successful change initiative (Nadler and Tushman, 1990; Lehman 2002; Kotter, 2007; Holt et al., 2007a). We call this phenomenon readiness for change.

Few leaders today would disagree with the idea that inviting those who will be affected to help create the change are more likely to increase their commitment as a precursor to successful implementation. But, the practical problem for leaders and organizations everywhere endures: how do you ensure that the people involved are committed to the change and convinced that they can execute on it successfully? This perennial question explains why change management is still a much sought-after leadership skill, the focus of some of the most demanded offerings in continuous business education, and a prominent consulting job.

The primary method for leaders to plan and initiate change in many organizations continues to be the same year after year: workshops, broadly defined. Workshops about tactical or strategic change are very common everywhere and companies spend hundreds of millions of dollars a year on them (Hodgkinson et al., 2006; Frisch and Chandler, 2006). While the literature on strategy as practice (e.g., Johnson et al., 2010; Henry and Seidl, 2013) sheds some light on the workshop phenomenon and the types of outcomes achieved, it neither describes how readiness for change is actually manifested during workshops, nor does it detail what key drivers have been identified. Based on an extensive analysis of empirical studies of change in the management literature, Oreg and Bersen (2019) proposed a model of change leadership and organizational change processes and outcomes. They found that two paths of leadership impact on recipients' reactions to change dominate the literature: leaders' choices about (macro-level) strategy and their (micro-level) behaviour. In terms of this literature, our study touches both paths. Our focus is on people (not just the leader) making sense of possible choices and their reactions during workshops facilitated by external experts.

In our study, we seek to contribute to the broader change management discourse, and within this vast field, to the literature on readiness for change. We also strive to offer practical advice on how to facilitate workshops to better drive change readiness.

This article consists of three sections. Because our epistemological stance in this study is positivism, we first construe from the literature a conceptual model of the existing definition of change readiness and identified the drivers. We then use this model to formulate hypotheses, and next convert it into a measurement model. To test the hypotheses, we use structural equation modelling of data from 374 participants of 69 workshops that were facilitated using an identical approach - LEGO® SERIOUS PLAY®. Our findings show which constructs have most predictive power. Our results have important implications for how to design and facilitate workshops to increase

International Journal of Management and Applied Research, 2020, Vol. 7, No. 1 
participants' readiness for change. Finally, we discuss these findings in view of the literature and offer concrete recommendations to workshop facilitators.

\section{An individual and social level construct}

Organizational change refers to the transition of the organization from one state to another. Lewin $(1947 ; 1951)$ famously argued that people experience three stages as they progress through change - unfreezing, changing and refreezing. Adding the importance of human behaviour and attitudes in change processes, others soon suggested ways to effectively reduce resistance to both the unfreezing phase and the progression all the way through. Many disciplines have since contributed to change theory, including education, psychology, management, organization studies, sociology and biology (see Van de Ven and Poole, 1995, for an exemplary summary of change theories applicable across all social sciences).

Readiness for change can be theorized, assessed and studied on any level but its meaning and relationship with other variables modulates somewhat across scale. An individual who is prepared for action does not mean the same when referring to a group, and neither is a single person's readiness for change the same as that of a collective.

One of the early insights was that employee participation in the change process made people more likely to achieve the goals (Coch and French, 1948) - and that insight still holds today. Practitioner-oriented literature include suggestions for how to "unfreeze" minds by demonstrating how the status quo performance is inadequate, creating a compelling vision of the future, persuading people that the vision can be achieved, and arguing that continuous change is the new normal (e.g., Kanter, 1984; Kotter, 2007). More than this, influencing peoples' emotions turns out to be one of the most important means through which leaders impact followers (Huy 2002; Huy et al., 2014).

The emerging literature on change readiness (e.g., Weiner 2009; Shea et al., 2014) conceptualizes this phenomenon as a function of buildings a shared psychological state in which organizational members feel committed to implementing the change and are confident in their collective abilities to do so. This literature often focuses on individuals' resistance to change and how to overcome it. For example, Holt et al. (2007a) outlined the relationship between possible drivers of readiness, developed a range of items capturing each, and used factor analysis of survey data to construct an instrument that reliably measures readiness at an individual level.

The principal unit of our analysis in this study is equally the individual. However, we examine groups of people in the same organisation, which means that the readiness to change drivers include both individual and social level phenomena. Consistent with this, we build on Weiner (2009) who empirically derived a model for determinants and outcomes of collective readiness for change. In the context of health care organizations, he recognized that any change initiative needed multiple and simultaneous changes in workflow, decision making, communication and performance management, and he labelled it organizational readiness for change. We take the same cross-level perspective.

International Journal of Management and Applied Research, 2020, Vol. 7, No. 1 


\section{Operationalizing readiness for change}

The collective readiness for change depends on what kind of initiative should be implemented (content), the steps proposed to implement the initiative (process), the attributes of environment where the initiative is implemented (context), and the people who are to implement the initiatives (attributes). To simplify, we build on Weiner's (2009) definition of organizational change readiness as a construct that incorporates both being psychologically willing and behaviourally able to take action: change commitment and change efficacy.

Change commitment is a private and a public activity where one identifies themselves with an interest and expresses it in front of others in the organization. It is about behaving actively and responsibly when developing, for example, strategic changes and being determined to implement them (Roos and Said, 2005). Organizational members have a shared resolve and are psychologically and behaviourally prepared to take the actions necessary to make the suggested changes. Change efficacy means organizational members share beliefs in their collective ability to get things done in the face of difficulties to realize the change.

Both change commitment and efficacy are precursors, or at least strong leading indicators, to what will happen when leaders initiate change. The logic is simple: the lower or higher the change commitment and efficacy, the lesser or greater the likelihood of getting the change implemented.

The two components may covary, but probably not extensively if change readiness is to take form. For example, a team may be convinced they can deal with all problems that may arise when implementing change, yet still not want to do it. Or a team may be highly committed to a change, but feel they are unable to make it happen in practice for all kinds of organization-level reasons outside their control.

In their pursuit to deepen Weiner's work, Shea et al. (2014) used a psychometric assessment of these two constructs. Over three empirical studies and by means of content adequacy assessments followed by factor analysis, they reduced a list of candidates to four change commitment and five change efficacy measures. Their findings represent simple, reliable and valid measurements of readiness for change, which we adapted in our study, though in modified form, as explained below.

While measures of the outcome variable readiness for change may have been validated, the literature still suffers from conceptual ambiguities and disagreements about quantitative psychometric assessments about what impacts it. In a recent review, the conclusion was that "...all [instruments] require further evaluation and validation...” (Puchalski Ritchie and Straus 2019: 56). We hope that our study can help remedy this problem.

\section{Causing readiness for change}

What causes readiness for change? The more generic change literature has generated a long list of possible predictors ranging from characteristics of employees, like openness to the work and disposition to change, to leaders' styles, such as how

International Journal of Management and Applied Research, 2020, Vol. 7, No. 1 
supportive and charismatic they are. However, this is of limited use to us. The literature on readiness for change has mostly focused on the outcome variables but outlines possible high-level drivers. For example, Weiner (2009) argued that culture, policies and past experience ("contextual factors") influence both (1) how organizational members value the upcoming change ("change valence") and (2) task demands, perceptions about resources, and the situation at hand ("informational assessment"). In turn, these two determine readiness for change. While this a starting point, we had to do a tour d'horizon review of adjacent fields to extract what constructs might cause collective readiness for change.

We isolated two indirect factors, Motivation and Psychological Safety, that have an impact on three direct causes: Engagement, Group Cohesion, and Knowledge Creation. Below we summarize the grounds for extracting these five constructs from the literature and how they affect readiness for change. In what follows, we briefly describe the main causal paths deducted from this review.

\subsection{Indirect causes}

\subsubsection{Motivation}

Motivation is what initiates, guides, and sustains goal-oriented behaviour make decisions and take action. There are many theories that explain motivation, ranging from basic instincts to desire for self-actualisation. Lehman et al. (2002) found that "motivational readiness" was the key for organisational readiness for change in previous research. This construct is certainly in line with most psychological theory: we act if and when we are motivated. Self-determination theory (Deci and Ryan, 1985) also suggests that motivation is divided into different sub-constructs that predict human behaviour differently.

For our purposes, the distinction between intrinsic and extrinsic motivation is helpful. We are intrinsically motivated when something is interesting or enjoyable to us, leading us to take action. Extrinsic motivation occurs when we are motivated to take action by someone else or something else. The literature divides extrinsic motivation into two kinds of "regulations" - external and identified. The former is being motivated by avoiding negative consequences, like the risk of demotion, and the latter is when our motivation is based on the prospect of receiving a reward, like a bonus. A third category, a motivation, is a lack of motivation because we are feeling helpless (Burton et al., 2006; Guay et al., 2000; Ryan and Deci, 2000).

We concur with Lehman et al. (2002) that motivation is an important component of readiness for change. While they focused on motivation to deal with a specific problem, we focus on the motivation to do something, i.e., the situational motivation that drives the change (Vallerand, 1997).

Motivation change over time, but our focus is on motivation at the start of a change process and we can deduce an indirect causal effect. Participants who are motivated to participate in an organisational change process are more likely to have a high Engagement and to create new Knowledge, which in turn can lead to an increased readiness for change (Cunningham et al., 2002; Richer et al., 2002; Xiong et al., 2015).

International Journal of Management and Applied Research, 2020, Vol. 7, No. 1 


\subsubsection{Psychological Safety}

The literature on psychological safety is dominated by Amy Edmonson's research findings (Edmondson, 1999 and 1996; Edmondson and Lei, 2014). The term refers to a shared belief within a team that it is in a safe environment for speaking up and taking interpersonal risks. If you invite team members to an open environment, the group's psychological safety becomes even stronger. But if a team member experiences the environment as threatening, for example, that a mistake will be held against him or that his knowledge and skills are not valued, he is less likely to share and contribute to the wider group (Carmeli et al., 2009).

Psychological safety also depends on who is leading or facilitating the conversations. Consequently, the relationship between the facilitator, whether internal or external, and the team is key to create overall safe environment (Tseng et al., 2009).

Another of the constructs that builds organisational readiness for change is safety among colleagues (Eby et al., 2000; Rafferty et al., 2009). Research into psychological safety suggests high quality relationships are necessary. When these exist, individuals in groups are more likely to focus on the collective group goals that are central for Group Cohesion (Carmeli and Gitell, 2009; Schein, 1992).

Psychological Safety is built by sharing information between group members, which increases creativity (Gong et al., 2012) and helps develop new insights and ideas (Baer and Frese, 2003). Team members are willing to speak up with suggestions for strategic improvements (Detert and Burris, 2007; Liang et al., 2012). These are all foundations of Knowledge Creation. Psychological Safety is also theorised to be an important foundation of Engagement in an organisation or in an activity (e.g., Kahn, 1990). This has been confirmed as well in later studies (e.g., May et al., 2004).

In sum, we propose that Motivation impacts Knowledge Creation and Engagement and that Psychological Safety drives Group Cohesion, Knowledge Creation and Engagement.

\subsection{Direct causes}

\subsubsection{Group cohesion}

Group cohesion refers to the glue that keeps a social system together and is often considered as the sum of forces that act on members to remain a group (Festinger, 1950). Cohesion may depend on the attractiveness or unattractiveness of the status of group, its members, or the prestige of what the group does.

Cohesion at work is traditionally seen as how much people like one another and collaborate within the group (Mullen and Copper, 1994). However, more recent studies conceive cohesion in terms of work performance and task cohesion. For example, group performance is more effective when people commit to a particular group task (Carless and de Paola, 2000; Carron et al., 1985). This kind of task cohesion can be defined as the collective motivation towards achieving the organisation's goals and objective.

International Journal of Management and Applied Research, 2020, Vol. 7, No. 1 
A cohesive group is more likely to address challenges that may hinder change, as the strong relationships within the group lead to a better understanding of the resources each participant can contribute and the collective support can make the change challenge easier (Beal et al., 2003; Kozlowski and Chao, 2012). As a result, the social relationships in the workplace are related to an increased readiness for change (Hanpachern et al., 1998).

\subsubsection{Knowledge Creation}

Previous research has shown that greater organisational knowledge is related to a greater readiness for change (Hanpachern et al., 1998; Rusly, Corner and Sun, 2012). We agree. In our experience, people are more ready for change if they can develop new insights and perspectives relating to the change.

If this is true, one of the important constructs to develop in a strategic workshop is the ability to create new knowledge regarding the organisation and its strategic potential (Healey et al., 2015). According to Healey et al., (2015), strategic workshops should be designed to allow members of an organisation to share knowledge with others, which in turn leads to higher Knowledge Creation about the organisation itself, as well as moving the strategic direction forward. Having greater understanding opens up opportunities to develop innovative solutions and the ability to do a better job (Choo et al., Grant, 1996; Nickerson and Zenger, 2004).

Change readiness is thus built on the participants' ability to understand both the 'know how' and 'know why' emerging from increased knowledge creation (Healey et al., 2015). The process of creating new knowledge in a group of people is often done by changing the way they think or behave, which can then lead to a change in the organisation (Chen, 2008; Holt et al., 2007a; Holt et al., 2007b).

\subsubsection{Engagement}

One of the earliest findings from change management studies is that being actively involved in change processes increases readiness to change (Coch and French, 1948; Cunningham et al., 2002). We consider involvement in terms of Engagement, which means concentration about, interest in, and enjoyment of the activity at hand.

People who are very engaged in a task can sometimes reach "peak performance" during which they become much more efficient, creative, and generally more productive (Garfield 1987; Privette et al., 1996; Thornton et al., 1999). Such peak performance can be a transformational experience for group members, “...suspending their perception of time, binding them together and being a source of great joy and inspiration" (Marotto et al., 2007: 388). This description resembles the individuallevel psychological state of "flow" which Csikszentmihalyi (1990) famously described as a mental state full of concentration and enjoyment which absorbs people into a task. Becoming fully engaged in a change process task can better happen when a group has high motivation and high psychological safety, which directly impacts their readiness for change (Cunningham et al., 2002; Kahn, 1990). This is because involvement in the change process can lead to team members to feel more engaged with the change and convince them that the change is the right way forward (Rusly et al., 2012).

International Journal of Management and Applied Research, 2020, Vol. 7, No. 1 
In sum, we suggest that Cohesion, Knowledge Creation and Engagement each directly impact Change Efficacy and Change Commitment as outlined in the conceptual model depicted in Figure 1 and the summary of the hypotheses in Table 1.

Figure 1: Conceptual model with hypotheses



Table 1: Summary of eight hypotheses with literature support

\section{Hypotheses Literature support}

H1 The more participants are Motivated to participate in the workshop, the more Knowledge Creation will occur

H2 The more participants are Motivated to participate in the workshop, the more Engaged they will be

H3 The higher level of Psychological Safety in the workshop, the more Knowledge Creation will occur

H4 The higher the level of Psychological Safety in the workshop, the more Group Cohesion there will be

H5 The higher the level of Psychological Safety in the workshop, the more Engaged participants will be

H6 The more Knowledge Creation that occurred in the workshop, the higher the readiness for Change

H7 The higher level of team Cohesion in the workshop, the higher the level of readiness for Change

$\mathrm{H} 8$ The more Engaged the participants are in the workshop, the higher level of change readiness
Richer et al. (2002); Xiong et al. (2015)

Cunningham et al. (2002); Richer et al. (2002); Xiong et al. (2015)

Baer and Frese (2003); Detert and Burris (2007); Gong et al. (2012); Liang et al. (2012)

Carmeli and Gitell (2009); Schein (1993)

May et al. (2004); Kahn (1990)

Chen (2008); Holt et al. (2007a); Hanpachern et al. (1998); Holt et al. (2007b); Russly et al. (2012)

Beal et al. (2003); Hanpachern et al. (1998); Kozlowski and Chao (2012)

Cunningham et al. (2002); Rusly et al. (2012)

International Journal of Management and Applied Research, 2020, Vol. 7, No. 1 


\section{From the conceptual to a measurement model}

Research on complex phenomena like change readiness is often characterized by variables that are not directly observable, and the direct and indirect effects may be more explorative. In addition, the independent, indirectly observed constructs may be correlated and are seldom free of noise or measurement errors, which can result in less reliable statistical inferences. For these reasons we apply structural equation modelling (SEM), which is a statistical analysis to assess causal relationships among such constructs that offers more potential for clarity between theory and data.

In SEM, the inner relations among the constructs - our hypotheses - are specified as stochastic, whereas the outer relationships of each construct are estimated as linear combinations of specific indicators. The resultant model of direct and indirect causes among constructs is captured by this set of indicators (rather than exact "measures"), which together make up the testable measurement model (Wold 1974; Fornell and Bookstein, 1987; for an example, see Yip et al., 1997).

There have been many studies validating our constructs, and we built on these to formulate our indicators. Motivation has previously been measured and validated by Situational Motivation Scale (Guay et al., 2000). Likewise, Amy Edmondson has operationalized Psychological Safety in a way that suits our purposes. However, we have added a measure from Tseng et al., (2009) to capture the essential relationship between facilitator and group. In the same vain, Choo et al. (2007) provided valid measures for Knowledge Creation; Carless and de Paola (2000) for Cohesion; and Ullén et al. (2012) for Engagement. We adapted the already validated measures for Change Commitment and Change Efficacy provided by Shea et al., (2014) by changing some phrasing, excluding two measures and adding one additional measure.

In sum, we derived a set of specific measurable indicators for each construct. We ended with 19 indicators that capture the essence of the five constructs and 4 indicators that reflect each of the two outcome constructs, Commitment and Efficacy. Table 2 list these as the exact questions we posed in the survey (Appendix 1 outlines how we derived these from the literature).

Table 2: Summary of all indicators used

\begin{tabular}{l}
\hline Indicators of Motivation \\
\hline I participated in the workshop because I believed that the activity was important for me \\
I participated in the workshop because the activity was fun \\
I participated in the workshop, but I am not sure it was worth my while \\
I participated in the workshop because I didn't have any choice \\
Indicators of Psychological Safety \\
My unique skills and talents were valued and utilized \\
You were able to bring up problems and tough issues \\
It was safe for me to take a risk \\
If you made a non-conventional suggestion, it was held against you \\
The facilitator helped create a secure environment
\end{tabular}

International Journal of Management and Applied Research, 2020, Vol. 7, No. 1 


\begin{tabular}{l}
\hline Indicators of Group Cohesion \\
Our team was united in trying to reach the goal \\
Our team was committed to the task \\
Our team members had conflicted aspirations \\
\hline Indicators of Knowledge Creation \\
\hline I generated many ideas \\
I found solutions that emerged as clearly innovative \\
\hline I increased my ability to do a better job \\
\hline Indicators of Engagement \\
\hline I got excited \\
\hline I developed a clear picture of what you want to achieve \\
\hline I felt completely concentrated \\
\hline I found the workshop extremely enjoyable \\
\hline Indicators of Change Commitment \\
\hline I was committed to implement relevant changes \\
\hline I was determined to implement this change \\
\hline I was motivated to implement this change \\
\hline I wanted to implement this change \\
\hline Indicators of Change Efficacy \\
\hline I was convinced I could coordinate tasks to smooth any implementation \\
\hline I was convinced I could support people as they adjust to changes \\
\hline I was convinced I could handle the challenges that may arise during implementation of \\
the changes \\
\hline I was convinced I would be supported in this change \\
\hline
\end{tabular}

\section{Methodology}

\subsection{Validating the measurement model}

To validate the conceptual model, our hypotheses and the measurement indicators, we first interviewed experienced change consultants and compared their inputs with our model. We chose to approach a population of consultants trained and certified in LEGO® SERIOUS PLAY® (LSP), which eliminated any bias from using different methods.

Because the first author is the co-inventor of this method, we had a hunch that consultants from this population would be open to participate in and contribute to the research. This turned out to be the case. Using a snowballing approach starting with one of the most experienced LSP facilitators worldwide, he identified 15 experienced facilitators willing to participate.

International Journal of Management and Applied Research, 2020, Vol. 7, No. 1 
To get inputs to refine and validate constructs, measurements and hypotheses, the second author interviewed (recorded) for one hour to one and a half hours each of the facilitators. These were open-ended interviews during which he neither revealed the conceptual model nor any preliminary measurements. The interview consisted of three parts. The first was open-ended and explorative and helped us tap into the experience of these facilitators. To this end, we asked questions like: "In your experience, during your workshops what makes people want to implement the changes discussed?" In the second part of the interview, we asked specific follow-up questions about each of the constructs of the conceptual model and any other questions prompted by the first part. Example questions included: "What do you mean by motivation, can you be more precise?" and "How did the group react if someone brought up anon-conventional idea?" The third part of the interview focused on exploring potential causes and effects among the constructs discussed relative to specific workshops they had facilitated, e.g., "Which was most important for them to buy into the upcoming change: their motivation or engagement?"

Throughout all interviews, facilitators consistently mentioned two or more of the constructs already included in the conceptual model. They did not mention any other constructs or rationales to explain change readiness, hence validating our constructs. Although they emphasised different causal paths as more important than others, we did not discover anything from these interviews that would exclude or change our eight hypotheses.

\subsection{Data}

To recruit facilitators who were open to help collect data from their own workshop participants, the first author identified and invited practitioners who described themselves as LSP facilitators on LinkedIn. A requirement was that they were trained and certified in this method by a qualified trainer under the Creative Commons License guidelines of 2010. In 2010 the LEGO Group decided to offer the LSP Methodology as a community-based model under the Creative Commons License Deed (CC BY-SA 3.0). Those who responded with interest and confirmed their active facilitator status received another LinkedIn message outlining the nature of the research and an invitation to participate. If they did respond positively, the second author contacted them with instructions about how to administer a participant survey following their next workshop(s).

Each facilitator was able to test the survey questions themselves and abort the process if uncomfortable. The online survey was set up in a way to ensure anonymity for the responders via-a-vis both facilitators and us. These arrangements are in line with our institution's research ethics principles and the research project was approved by its Research Ethics Committee prior to any data collection.

To ensure similar meaning across languages, the survey was translated into five languages by Qualtrics Translation Services and was back translated by a separate translator. One of the versions was translated by an independent translator and validated by an unrelated native speaker of that language.

International Journal of Management and Applied Research, 2020, Vol. 7, No. 1 
For this research, 36 facilitators administrated survey data from 374 participants attending 69 workshops in organizations. All five languages were used, but the most used were English (74\%) and Spanish (12\%). The average number of respondents per workshop was 5. We collected this data from September 2018-December 2019.

\subsection{Data analysis}

The data was analysed in two stages. First, we did an initial Confirmatory Factor Analysis (CFA) and followed this up by calculating a Structural Equation Model (SEM) to test the hypothesis.

Participants came from 69 different workshops, and since the median number of participants $(\mathrm{med}=3$ ) of each workshop and the intraclass correlations $(<.10)$ are low, we applied a single level CFA using Maximum Likelihood (ML) estimation instead of a Multilevel CFA. The results should remain unbiased (Julian, 2001; Duncan et al., 1997). The analysis showed that almost all measures significantly loaded onto their respective constructs. However, one measure of Psychological Safety and one of Cohesion had small loadings $(0.3, p=.01$, and $0.2, p=.036$ when it should be above 0.4 ), which reduced the overall fit of the measurement model to between low and acceptable $\left(\mathrm{X}^{2}[303]=829.24, p<.001, \mathrm{CFI}=.91, \mathrm{TLI}=.89, \mathrm{RMSEA}=.068[.063-\right.$ $.074]$, SRMR =.06).We suspect that the reason for the low loading was their reverse scale, which we had intentionally designed to avoid having people just tick boxes without reflecting. When we did the second order CFA without these two measures, the model fit improved to $\operatorname{good}\left(\mathrm{X}^{2}[250]=506.21, p<.001, \mathrm{CFI}=.95\right.$, TLI $=.94$, RMSEA $=.052[.046-.059]$, SRMR = .04.) Because this would only reduce the measures from four to three, we decided to omit these from further analysis. See table 3 for correlation coefficients, Means of the construct and finalised Cronbach alphas.

Table 3: Pearson's Correlations, means, standard deviations and Cronbach alpha coefficients

\begin{tabular}{|c|c|c|c|c|c|c|c|c|c|}
\hline & 1. & 2. & 3. & 4. & 5. & 6. & 7. & Mean & $\alpha$ \\
\hline 1. Motivation & - & & & & & & & $5.41(1.15)$ & .66 \\
\hline 2. Psychological safety & $.53 * * *$ & - & & & & & & $5.63(1.00)$ & .84 \\
\hline 3. Cohesion & $.37 * * *$ & $.50 * * *$ & - & & & & & $5.98(0.98)$ & .88 \\
\hline 4. Insights & $.48 * * *$ & $.55^{* * *}$ & $.49 * * *$ & - & & & & $5.18(1.11)$ & .83 \\
\hline 5. Engagement & $.51 * * *$ & $.59 * * *$ & $.48 * * *$ & $.68 * * *$ & - & & & $3.76(0.71)$ & .82 \\
\hline 6. Change commitment & $.39 * * *$ & $.46^{* * *}$ & $.41 * * *$ & $.59 * * *$ & $.57 * * *$ & - & & $3.90(0.73)$ & .89 \\
\hline 7. Change efficacy & $.30 * * *$ & $.46 * * *$ & $.39 * * *$ & $.57 * * *$ & $.55^{* * *}$ & $.83 * * *$ & - & $3.83(0.70)$ & .86 \\
\hline
\end{tabular}

\subsection{Hypothesis testing}

The result of the ML estimation is presented in Figure 2. We used the measures from the CFA in a SEM and the model remained good when adding the hypotheses into the calculations $\left(x^{2}[260]=536.61, p<.01, \mathrm{CFI}=.95, \mathrm{TLI}=.94, \mathrm{RMSEA}=.05[.047-\right.$ $.060]$, SRMR = .04). The path analysis of the SEM indicated that there were significant positive relationships between Motivation and Engagement, and that Motivation

International Journal of Management and Applied Research, 2020, Vol. 7, No. 1 
significantly predicted an increase in Knowledge Creation. The result is that both Hypothesis 1 and 2 are accepted.

Psychological Safety significantly predicted an increase in Cohesion. However, Psychological Safety did not significantly predict Engagement or Knowledge Creation. This means that Hypothesis 4 is accepted while Hypotheses 3 and 5 are rejected.

We therefore conducted a revised path analysis to analyse the relationship between Cohesion and Engagement as well as Cohesion and Knowledge Creation. These results indicated that Cohesion, not Psychological Safety, predicted increases in Engagement and Knowledge Creation.

The two constructs of readiness for change, Commitment and Efficacy, were both significantly predicted by Creating Knowledge and by Engagement. These findings conclude the model by accepting Hypotheses 7 and 8 .

\subsection{Simplifying the model}

The loadings of the paths from Knowledge Creation and Engagement to the two change constructs are of equal size, and the internal consistency of the indicators is stronger as one merged construct compared to two independent constructs $(\alpha=.93)$. Therefore, we re-estimated the data with a model that merged the two change constructs into one, Readiness for Change. The strength of the paths changed only marginally with a single change construct, and the model fit from the confirmatory factor analysis was only marginally lower. The resulting six significant Hypotheses enables us to present simplified model of what drives readiness for change in our context, as depicted in Figure 2.

As can be seen in Figure 2, most of the hypotheses survived contact with real data from workshops in organizations. However, a surprising finding from the analysis was that Cohesion indirectly drives readiness for change via Knowledge Creation and Engagement rather than the hypothesized direct relationship. This would suggest that Psychological Safety increases the Group Cohesion in terms of stronger bonds and unity in the group. The perceived safety and the strong bonds in the group allow members to share their knowledge and enable engagement in the workshop (Kozlowski and Chao, 2012), which in turn increased readiness for change.

Holt et al. (2007a) concluded that readiness for change is influenced by beliefs among employees that they are capable of implementing a proposed change, the change is appropriate for the organization, the leaders are committed, and that the proposed change is beneficial to people involved. Our findings also stress the importance of Motivation to take part in change discussions, especially when workshops are seen as important to the individual. It may be that our specific research setting explains the need for such a priori "self-interest," but our study shows its predictive power for how much participants engage and the likelihood of gaining new insights.

International Journal of Management and Applied Research, 2020, Vol. 7, No. 1 
Figure 2: Simplified model of what drives readiness for change

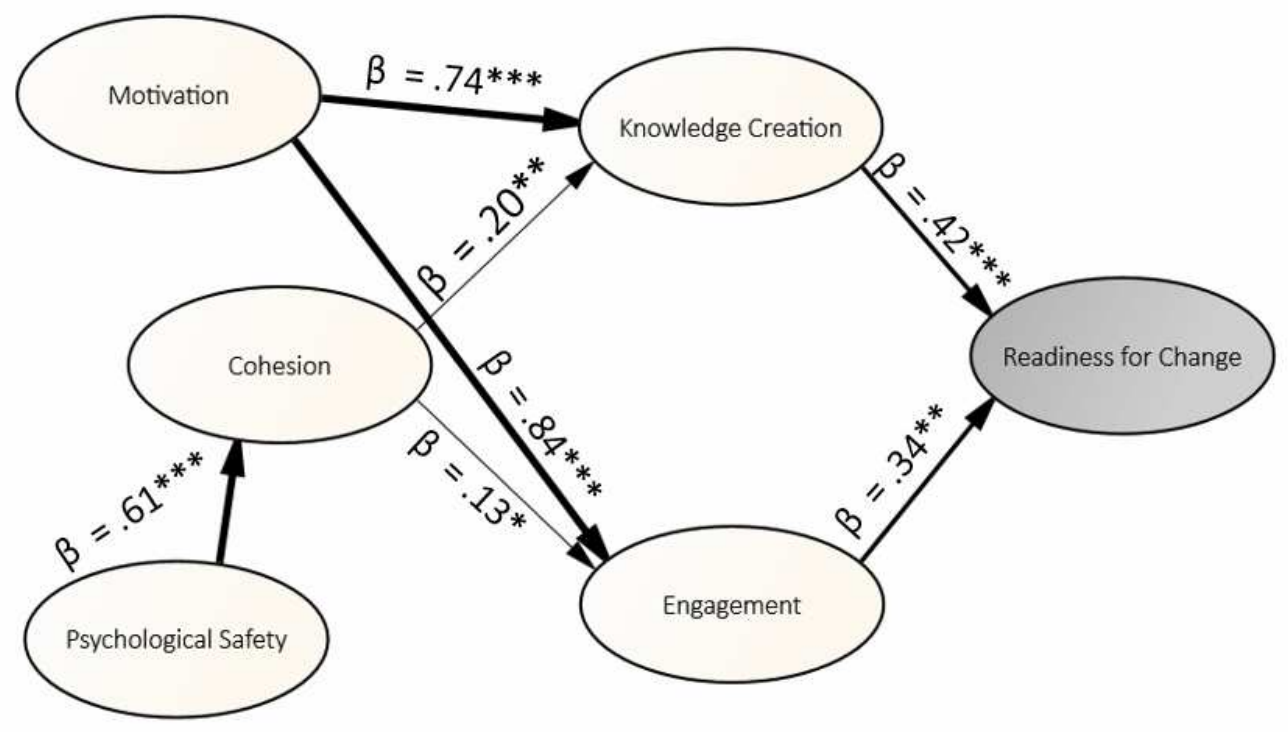

Standardized beta coefficients for hypothesized path, $*=p<.05, * *=p<.01, * * *=p$ $<.001$. Standardized beta coefficients of the Change Commitment and Change Efficacy in the original model were from Knowledge Creation $(\mathrm{CC}=\beta=.42 p<.001, \mathrm{CE}=\beta=$ $.39, p<.01)$, and from Engagement $(\mathrm{CC}=\beta=.34 p<.01, \mathrm{CE}=\beta=.33, p<.01)$.

\subsection{Strengths of indicators}

All measures loaded significantly onto their theorized construct and the majority ranged between .60 to .85 , indicates strong loadings. The items and constructs also showed good construct validity, i.e., they measure what they intend to measure. To simplify the analysis, Table 4 shows the strongest indicators to define the primary meaning for each construct (all indicators can be found in Appendix 2).

Table 4: The strongest indicator per construct

\begin{tabular}{llc}
\hline Construct & Defined as & Loading \\
\hline Motivation & $\begin{array}{l}\text { I participated in the workshop because I } \\
\text { believed that the activity was important for } \\
\text { me }\end{array}$ & $\beta=.72^{* * *}$ \\
Psychological Safety & $\begin{array}{l}\text { My unique skills and talents were valued and } \\
\text { utilized } \\
\text { Our team was united in trying to reach the } \\
\text { goal }\end{array}$ & $\beta=.80^{* * *}$ \\
Cohesion & $\begin{array}{l}\text { I found solutions that emerged clearly } \\
\text { innovative }\end{array}$ & $\beta=.89^{* * * *}$ \\
Knowledge Creation & $\begin{array}{l}\text { You developed a clear picture of what you } \\
\text { want to achieve }\end{array}$ & $\beta=.75^{* * *}$ \\
Engagement & I was motivated to implement this change & $\beta=.83^{* * *}$ \\
\hline Readiness for Change & $\begin{array}{l}\text { Note: } \text { Strength of top indicators of each construct using standardized beta values. } *=p \\
<.05, * *=p<.01, * * *=p\end{array}$
\end{tabular}

International Journal of Management and Applied Research, 2020, Vol. 7, No. 1 


\section{Discussion}

In this article, we set out to address the practical problem in organizations of how to ensure that people are committed to necessary change and convinced that they can execute it successfully. The article makes three broad contributions to the theory and research.

First, we add to the emerging readiness for change literature in two ways. Weiner's (2009) model about readiness for change as a shared psychological state. Our model of five drivers makes concrete the basic drivers of what Weiner labelled change valence and situational factors. Whereas he discusses change valence as an abstract phenomenon ("... a parsimonious construct that brings some theoretical coherence to the numerous and disparate drivers of readiness that change management experts and scholars have discussed...”, Ibid. p.3), our Engagement and Knowledge (new insights) constructs make this more concrete. We also further validate much of Shea et al., (2014). We also contribute a comprehensive conceptual model and transformed it into a testable measurement model of possible drivers of readiness for change, and concrete estimates about its predictive powers. This extends Weiner (2009) and Shea et al., (2014) as well as responds to the critique by Puchalski Ritchie and Straus (2019). Our study also responds to the latter's call for more empirical research on change in settings beyond the health care sector and the US middle-income setting.

Second, by focusing on the practice of developing change readiness during real workshops facilitated by professional practitioners, we also contribute to the literature about the use and benefit of "strategic workshops" as discussed in the strategy as practice field (e.g., Johnson et al., 2010; Henry and Seidl, 2013). While others have highlighted the roles that leaders play in shaping meanings of the change (Isabella, 1990) and how people think about it (Balogun and Johnson, 2004), we contribute a study of what drives participants of facilitated workshop to make sense of the change and deem themselves and the group ready to get it done.

Third, we already know that leaders' choices about strategy and their behaviour matter for the subsequent change (see Oreg and Bersen, 2019). This also relate to the literature on sense giving and sense making (Gioia and Chittipeddi, 1991). Our focus on how participants (not just the leader) make sense of possible choices and their reactions during workshops facilitated by external experts shed some light on the cognitive processes through which people in groups interpret and respond to change based on collective sensemaking.

\subsection{Limitations}

The specific context and cross-sectional data of our study limits, of course, the generalizability of our findings. The setting for our study was that of perceived levels of behavioural and psychological considerations during workshops in different types of organizations, in different parts of the worlds, and facilitated by different consultants, and in different languages. Furthermore, the data in this research was all self-reported. Even if the construct reliability of the data was overall excellent for the measures and self-reported measures of motivations and attitudes have shown to be reliable (Spector, 2006), we cannot guarantee that the bias of the self-reported data has

International Journal of Management and Applied Research, 2020, Vol. 7, No. 1 
not impacted the findings of this study. In principle, our findings are valid only for workshops of the same kind given that our data was collected from and based on the same workshop methodology (LSP), perhaps also under similar circumstances. Furthermore, because the data was collected immediately after the workshops, we did not capture any long-term outcomes of the workshops in terms of the successful performance of the implemented changes.

In sum, while our model to assess readiness for change demonstrates relatively good reliability and validity based on evaluations reported to date, we agree with Puchalski Ritchie and Straus (2019) that all current models, including ours, require further evaluation and validation. To complement cross-sectional and variance studies, we suggest longitudinal, process studies that measure change outcomes over time.

\section{Recommendations to practitioners}

Despite these limitations, we allow ourselves to turn normative since our aim is to help improve practice. We suggest that our model (Figure 2) can be converted to the following narrative about how to best facilitate workshops to drive readiness for change:

First ensure that people are motivated to join the workshop since that will drive how much they engage and the likelihood of their gaining new insights. Second, ensure psychological safety and group cohesion because that will drive both engagement and the potential for new insights.

Although the two main causal paths are addressed, some may say this advice still remains vague. However, if we focus on the indicator that captured most variance within each construct (table 3 ), we can make this narrative far more concrete:

To boost participants' readiness for change, we offer this advice to workshop facilitators:

1. Ensure that people participate in the workshop because they feel it is important to them;

2. Design the workshop so that each participant's skills are valued and utilized;

3. Ensure that the group is really united in reaching a goal;

4. Help participants develop a clear picture of what they want to achieve; and

5. Connect emerging insights to how the group could do an even better job.

The first author had the opportunity to discuss the preliminary findings and the advice at the $3^{\text {rd }}$ International LSP Conference in Denmark, 28-29 Oct 2019, which included some of the highly experienced facilitators who administered data for this project. The entire audience reactions in the form of affirmative nods, positive body language, verbal expressions of recognition and agreement, and willingness to contribute examples from their own consulting practices lent credence to our findings. There was no dissension from these conclusions.

International Journal of Management and Applied Research, 2020, Vol. 7, No. 1 
These findings and suggestions also align completely with our own decades of professional experience. We know from action research, executive education, strategy consulting, board membership, and C-suite work that generating a shared sense of readiness for change is very difficult. We are, however, already seeing greater positive results by making the model an integral part of our own leadership practice.

\section{Acknowledgement}

We thank Micael Buckle for inspiration to research this topic, Deepali D'mello for her persistent help to contact many facilitators to join this research, the many LEGO ${ }^{\circledR}$ SERIOUS PLAY® facilitators who motivated their participants to contribute data, Rick Benzel for helping improve the manuscript, and the anonymous reviewer feedback. The project was funded by HULT International Business School, which we gratefully acknowledge.

\section{References}

1. Baer, M. and Frese, M. (2003), "Innovation is not enough: Climates for initiative and psychological safety, process innovations, and firm performance", Journal of Organizational Behavior, Vol. 24, No. 1, pp. 45-68. https://doi.org/10.1002/job.179

2. Balogun, J. and Johnson, G. (2004), "Organizational restructuring and middle manager sensemaking", Academy of Management Journal, Vol. 47, No. 4, pp. 523-549. https://doi.org/10.5465/20159600

3. Beal, D.J., Cohen, R.R., Burke, M.J. and McLendon, C.L., (2003), "Cohesion and performance in groups: a meta-analytic clarification of construct relations", Journal of applied psychology, Vol. 88, No. 6, pp. 989-1004. https://doi.org/10.1037/0021-9010.88.6.989

4. Burton, K.D., Lydon, J.E., D’Alessandro, D.U. and Koestner, R., (2006), “The differential effects of intrinsic and identified motivation on well-being and performance: prospective, experimental, and implicit approaches to selfdetermination theory", Journal of personality and social psychology, Vol. 91, No. 4, pp.750-762. https://doi.org/10.1037/0022-3514.91.4.750

5. Carron, A.V., Widmeyer, W.N. and Brawley, L.R., (1985), "The development of an instrument to assess cohesion in sport teams: The Group Environment Questionnaire", Journal of Sport and Exercise psychology, Vol. 7, No. 3, pp. 244266.

6. Carless, S.A. and De Paola, C., (2000), "The measurement of cohesion in work teams", Small group research, Vol. 31, No. 1, pp.71-88. https://doi.org/10.1177/104649640003100104

7. Carmeli, A. And Gittell, J.H., (2009), "High-quality relationships, psychological safety, and learning from failures in work organizations", Journal of

International Journal of Management and Applied Research, 2020, Vol. 7, No. 1 
Organizational Behavior, Vol. 30, No. 6, pp. 709-729. https://doi.org/10.1002/job.v30:610.1002/job.565

8. Chen, C.A., (2008), "Linking the knowledge creation process to organizational theories", Journal of Organizational Change Management, Vol. 21, No. 3, pp. 259 - 279. https://doi.org/10.1108/09534810810874778

9. Choo, A.S., Linderman, K.W. and Schroeder, R.G., (2007), "Method and psychological effects on learning behaviors and knowledge creation in quality improvement projects", Management Science, Vol. 53, No.3, pp.437-450. https://doi.org/10.1287/mnsc.1060.0635

10. Coch, L. and French Jr, J.R., (1948), "Overcoming resistance to change", Human relations, Vol. 1 No. 4, pp.512-532. https://doi.org/10.1177/001872674800100408

11. Czikszentmihalyi, M. (1990, Flow: The psychology of optimal experience. New York: Harper \& Row.

12. Cunningham, C.E., Woodward, C.A., Shannon, H.S., MacIntosh, J., Lendrum, B., Rosenbloom, D. and Brown, J., (2002), "Readiness for organizational change: A longitudinal study of workplace, psychological and behavioural correlates", Journal of Occupational and Organizational psychology, Vol. 75, No.4, pp.377-392. https://doi.org/10.1348/096317902321119637

13. Deci, E. L., and Ryan. R. M., (1985), Intrinsic motivation and self-determination in human modelling. New York: Plenum.

14. Detert, J.R. and Burris, E.R., (2007), "Leadership Behavior and Employee Voice: Is the Door Really Open?", Academy of management journal, Vol. 50, No. 4, pp.869-884. https://doi.org/10.5465/amj.2007.26279183

15. Duncan, T.E., Duncan, S.C., Alpert, A., Hops, H., Stoolmiller, M. and Muthen, B., (1997), "Latent variable modelling of longitudinal and multilevel substance use data", Multivariate Behavioral Research, Vol. 32, No. 3, pp.275-318. https://doi.org/10.1207/s15327906mbr3203_3

16. Eby, L.T., Adams, D.M., Russell, J.E. and Gaby, S.H., (2000), "Perceptions of organizational readiness for change: Factors related to employees' reactions to the implementation of team-based selling", Human relations, Vol. 53, No. 3, pp.419442. https://doi.org/10.1177\%2F0018726700533006

17. Edmondson, A.C., (1996), "Learning from mistakes is easier said than done: Group and organizational influences on the detection and correction of human error", The Journal of Applied Behavioral Science, Vol. 40, No. 1, pp.66-90. https://doi.org/10.1177/0021886396321001

18. Edmondson, A., (1999), "Psychological safety and learning behaviour in work teams", Administrative science quarterly, Vol. 44, No. 2, pp.350-383. https://doi.org/10.2307/2666999

International Journal of Management and Applied Research, 2020, Vol. 7, No. 1 
19. Edmondson, A.C. and Lei, Z., (2014), "Psychological safety: The history, renaissance, and future of an interpersonal construct", Annual Review of Organizational Psychology and Organizational Behavior, Vol. 1, No. 1, pp.23-43. https://doi.org/10.1146/annurev-orgpsych-031413-091305

20. Festinger, L., Schachter, S. and Back, K., (1950), Social pressures in informal groups; a study of human factors in housing. New York: Harper.

21. Fornell,. C., and Bookstein, F. (1987), "A comparative analysis of two structural equation models: LISREL and PLS applied to market data", in C. Fornell (Ed), A Second Generation of Multivariate Analysis, New York: Praeger, pp. 289-324.

22. Frisch, B. and Chandler, L., (2006), "Off-sites that work", Harvard business review, Vol. 84 No. 6, pp.117-126.

23. Garfield, C. (1987), "Peak performances in business", Training and Development Journal, Vol. 23, pp. 54-59.

24. Gigliotti, R., Vardaman, J., Marshall, D.R. and Gonzalez, K. (2019), "The role of perceived organizational support in individual change readiness", Journal of Change Management, Vol. 19, No. 2, pp.86-100. https://doi.org/10.1080/14697017.2018.1459784

25. Gioia, D. A. and Chittipeddi, K. (1991), "Sensemaking and sensegiving in strategic change initiation", Strategic Management Journal, Vol. 12, No. 6, pp. 433-448. https://doi.org/10.1002/smj.4250120604

26. Gong, Y., Cheung, S.Y., Wang, M. and Huang, J.C. (2012), "Unfolding the proactive process for creativity: Integration of the employee proactivity, information exchange, and psychological safety perspectives", Journal of management, Vol. $\quad 38, \quad$ No. $\quad 5, \quad$ pp.1611-1633. https://doi.org/10.1177/0149206310380250

27. Grant, R.M., (1996), “Toward a knowledge-based theory of the firm”, Strategic management journal, Vol. 17, No. S2, pp.109-122.

https://doi.org/10.1002/smj.4250171110

28. Guay, F., Valler and, R.J. and Blanchard, C., (2000), "On the assessment of situational intrinsic and extrinsic motivation: The Situational Motivation Scale (SIMS)", Motivation and emotion, Vol. 24, No.3, pp.175-213. https://doi.org/10.1023/A:1005614228250

29. Hamari, J., Shernoff, D.J., Rowe, E., Coller, B., Asbell-Clarke, J. and Edwards, T. (2016), "Challenging games help students learn: An empirical study on engagement, flow and immersion in game-based learning", Computers in Human Behaviour, Vol. 54, pp.170-179. https://doi.org/10.1016/j.chb.2015.07.045

International Journal of Management and Applied Research, 2020, Vol. 7, No. 1 
30. Hanpachern, C., Morgan, G.A. and Griego, O.V. (1998), "An extension of the theory of margin: A framework for assessing readiness for change", Human Resource Development Quarterly, Vol. 9, No. 4, pp.339-350. https://doi.org/10.1002/hrdq.3920090405

31. Healey, M.P., Hodgkinson, G.P., Whittington, R. and Johnson, G. (2015), "Off to plan or out to lunch? Relationships between design characteristics and outcomes of strategy workshops", British Journal of Management, Vol. 26, No.3, pp.507-528. https://doi.org/10.1111/1467-8551.12038

32. Hendry, J. and Seidl, D. (2003), "The structure and significance of strategic episodes: Social systems theory and the routine practices of strategic change", Journal of management Studies, Vol. 40, No. 1, pp.175-196. https://doi.org/10.1111/1467-6486.00008

33. Hodgkinson, G.P., Whittington, R., Johnson, G. and Schwarz, M., (2006), "The role of strategy workshops in strategy development processes: Formality, communication, co-ordination and inclusion", Long range planning, Vol. 39, No. 5, pp. 479-496. https://doi.org/10.1016/j.lrp.2006.07.003

34. Holt, D.T., Armenakis, A.A., I, H.S. and Harris, S.G. (2007a), "Readiness for organizational change: The systematic development of a scale", The Journal of Applied Behavioral Science, Vol. 43, No. 2, pp. 232-255. https://doi.org/10.1177/0021886306295295

35. Holt, D.T., Bartczak, S.E., Clark, S.W. and Trent, M.R., (2007b), “The development of an instrument to measure readiness for knowledge management", Knowledge Management Research \& Practice, Vol. 5, No. 2, pp.75-92. https://doi.org/10.1057/palgrave.kmrp.8500132

36. Huy, Q. N. (2002), "Emotional balancing of organizational continuity and radical change: The contribution of middle managers", Administrative Science Quarterly, Vol. 47, No. 1, pp. 31-69. https://doi.org/10.2307/3094890

37. Huy, Q. N., Corley, K. G., and Kraatz, M. S. (2014), "From support to mutiny: Shifting legitimacy judgments and emotional reactions impacting the implementation of radical change", Academy of Management Journal, Vol. 57, No. 6, pp. 1650-1680. https://doi.org/10.5465/amj.2012.0074

38. Isabella, L. A. (1990), "Evolving interpretations as a change unfolds: How managers construe key organizational events", Academy of Management Journal, Vol. 33, No., 1, pp.7-41. https://doi.org/10.5465/256350

39. Johnson, G., Prashantham, S., Floyd, S.W. and Bourque, N. (2010), "The ritualization of strategy workshops", Organization Studies, Vol. 31, No. 12, pp.1589-1618. https://doi.org/10.1177/0170840610376146

International Journal of Management and Applied Research, 2020, Vol. 7, No. 1 
40. Julian, M.W., (2001), "The consequences of ignoring multilevel data structures in non-hierarchical covariance modelling", Structural Equation Modeling, Vol. 8, No. 3, pp. 325-352.

41. Kahn, W.A., (1990), "Psychological conditions of personal engagement and disengagement at work", Academy of management journal, Vol. 33, No.4, pp.692724. https://doi.org/10.5465/256287

42. Kanter R.M., (1984), The change masters: innovation and entrepreneurship in the American corporation, New York: Simon and Schuster.

43. Kotter, J. R. (2007), "Leading change: Why transformation efforts fail", Harvard business review, Vol. 85, No. 1, pp. 96-103.

44. Kozlowski, S.W. and Chao, G.T., (2012), "The dynamics of emergence: Cognition and cohesion in work teams", Managerial and Decision Economics, Vol. 33, No.56, pp.335-354. https://doi.org/10.1002/mde.2552

45. Lehman, W.E., Greener, J.M. and Simpson, D.D., (2002), “Assessing organizational readiness for change", Journal of substance abuse treatment, Vol. 22 No. 4, pp.197-209. https://doi.org/10.1016/S0740-5472(02)00233-7

46. Lewin, K. (1947), "Group decision and social change", in Maccoby, E. E.; Newcomb, T. M. and Hartley, E. L. (Eds.) Readings in Social Psychology, New York: Holt, Rinehart \& Winston, pp. 197-211

47. Lewin, K. (1951), Field theory in social science. New York: Harper.

48. Liang, J., Farh, C.I. and Farh, J.L., (2012), "Psychological antecedents of promotive and prohibitive voice: A two-wave examination", Academy of Management journal, Vol. 55, No. $1, \quad$ pp.71-92. https://doi.org/10.5465/amj.2010.0176

49. Marotto, M., Roos, J., and B. Victor, (2007), "Collective Virtuosity", Journal of Management Studies, Vol. 44, No. 3, pp. 388-413. https://doi.org/10.1111/j.14676486.2007.00682.x

50. May, D.R., Gilson, R.L. and Harter, L.M., (2004), “The psychological conditions of meaningfulness, safety and availability and the engagement of the human spirit at work", Journal of occupational and organizational psychology, Vol. 77, No. 1, pp.11-37. https://doi.org/10.1348/096317904322915892

51. Mullen, B. and Copper, C., (1994), "The relation between group cohesiveness and performance: An integration", Psychological bulletin, Vol. 115, No. 2, pp. 210227.

52. Nadler, D. A., and Tushman, M. L. (1990), "Beyond the charismatic leader: Leadership and organizational change", California management review, Vol. 32, No. 2, pp. 77-97. https://doi.org/10.2307/41166606

International Journal of Management and Applied Research, 2020, Vol. 7, No. 1 
53. Nickerson, J.A., and Zenger, T.R., (2004), "A knowledge-based theory of the firm-The problem-solving perspective", Organization science, Vol. 15, No. 6, pp.617-632. https://doi.org/10.1287/orsc.1040.0093

54. Oreg, S., and Berson, Y. (2019), "Leaders' impact on organizational change: bridging theoretical and methodological chasms", Academy of Management Annals, Vol. 13, No. 1, pp. 272-307. https://doi.org/10.5465/annals.2016.0138

55. Privette, G., Lanier, L. S., Vodanovich, S. J. and Bundrick, C. M., (1996), "Peak experiences: lasting consequences and breadth of occurrences among realtors, artists, and a comparison group", Journal of Social Behavior and Personality, Vol. 11, No. 4, pp. 781-782.

56. Puchalski Ritchie, L.M., and Straus, S.E. (2019), "Assessing organizational readiness for change: Comment on Development and content validation of a transcultural instrument to assess organizational readiness for knowledge translation in healthcare organizations: the OR4KT", International Journal of Health Policy and Management., Vol. 8, No. 1, pp. 55-57. https://doi.org/10.15171/ijhpm.2018.101

57. Rafferty, A.E., Jimmieson, N.L. and Armenakis, A.A., (2013), "Change readiness: A multilevel review", Journal of management, Vol. 39, No. 1, pp.110-135. https://doi.org/10.1177/0149206312457417

58. Richer, S.F., Blanchard, C. and Vallerand, R.J., (2002), "A motivational model of work turnover", Journal of Applied Social Psychology, Vol. 32, No.10, pp.20892113. https://doi.org/10.1111/j.1559-1816.2002.tb02065.x

59. Roos, J. and Said, R., (2005), "Generating managerial commitment and responsibility", European Management Review, Vol. 2, No. 1, pp.48-58. https://doi.org/10.1057/palgrave.emr.1500027

60. Rusly, F.H., Corner, J.L. and Sun, P., (2012), "Positioning change readiness in knowledge management research", Journal of Knowledge Management, Vol. 16, No. 22, pp. 329-355. https://doi.org/10.1108/13673271211218906

61. Ryan, R.M. and Deci, E.L., (2000), "Intrinsic and extrinsic motivations: Classic definitions and new directions", Contemporary educational psychology, Vol. 25, No. 1, pp. 54-67. https://doi.org/10.1006/ceps.1999.1020

62. Schein, E.H., (1992), "How can organizations learn faster?: the problem of entering the Green Room", Sloan management review, Vol. 34, pp.85- 92.

63. Shea, C.M., Jacobs, S.R., Esserman, D.A., Bruce, K. and Weiner, B.J., (2014), "Organizational readiness for implementing change: a psychometric assessment of a new measure", Implementation Science, Vol. 9, No.7. https://doi.org/10.1186/1748-5908-9-7

International Journal of Management and Applied Research, 2020, Vol. 7, No. 1 
64. Spector, P.E., (2006), "Method variance in organizational research: truth or urban legend?", Organizational research methods, Vol. 9, No. 2, pp. 221-232. https://doi.org/10.1177/1094428105284955

65. Thornton, F., Privette, G. and Bundrick, C. M. (1999), "Peak performance of business leaders: an experience parallel to self-actualization theory", Journal of Business and Psychology, Vol. 14, No. 2, pp. 253-64. https://doi.org/10.1023/A:1022143225092

66. Tseng, H., Ku, H.Y., Wang, C.H. and Sun, L. (2009), "Key factors in online collaboration and their relationship to teamwork satisfaction", Quarterly Review of Distance Education, Vol. 10, No. 2, pp. 195-206.

67. Ullén, F., de Manzano, Ö., Almeida, R., Magnusson, P.K., Pedersen, N.L., Nakamura, J., Csíkszentmihályi, M. and Madison, G. (2012), "Proneness for psychological flow in everyday life: Associations with personality and intelligence", Personality and Individual Differences, Vol. 52, No. 2, pp.167-172. https://doi.org/10.1016/j.paid.2011.10.003

68. Vallerand, R.J. (1997), "Toward a hierarchical model of intrinsic and extrinsic motivation", Advances in experimental social psychology. Vol. 29, pp. 271-360. https://doi.org/10.1016/S0065-2601(08)60019-2

69. Van de Ven, A.H. and Poole, M.S., (1995), "Explaining development and change in organizations", Academy of management review, Vol. 20, No.3, pp.510-540. https://doi.org/10.5465/amr.1995.9508080329

70. Weiner, B.J. (2009), "A theory of organizational readiness for change", Implementation science, Vol. 4, No. 67. https://doi.org/10.1186/17485908-4-67

71. Wold, H. (1974), "Causal flows with latent variables", European Economic Review, Vol. 5, pp. 67-86. https://doi.org/10.1016/0014-2921(74)90008-7

72. Xiong, Y., Li, H., Kornhaber, M.L., Suen, H.K., Pursel, B. and Goins, D.D. (2015), "Examining the relations among student motivation, engagement, and retention in a MOOC: A structural equation modeling approach", Global Education Review, Vol. 2, No. 3, pp. 23-33.

73. Yip. G., Johanson, J., and Roos, J. (1997), "Effects of Nationality on Global Strategy", Management International Review, Vol. 37, No. 4, pp. 365-386.

International Journal of Management and Applied Research, 2020, Vol. 7, No. 1 


\section{Appendix 1 - Grounding the indicators in the literature}

This appendix provides further details about how we were able to ground the selected indicators in our model in existing literature.

Motivation. Motivation was measured with four measures on a Likert scale ranging from (1) 'corresponds not at all' to (7) 'corresponds exactly', and the measures were adapted from the Situational Motivation Scale (SIMS). According to Guayet al., (2000), SIMS has been validated from five different studies in order to assess four constructs of Motivation, which are Intrinsic Motivation, Identified Regulation, External Regulation and A motivation. We adapted one item from each of the motivational constructs that suited the purpose of the study in the workshops.

Psychological safety. Psychological Safety was measured using the Psychology Safety construct developed by Edmondson's (1999). This construct was developed for the purpose of measuring a shared belief within a team that it is safe to share, take risks and speak up in organizational teams. The original paper included seven measures and were measured on a scale from (1) 'Very inaccurate' to (7) 'Very accurate'. Four of these measures were used and adapted to suit the environment found in an LSP workshop. The Psychological Safety construct was developed from qualitative interviews and the analysis of the psychometric constructs indicated on a high consistency reliability (Edmondson, 1999). Furthermore, an adapted version of the psychological construct was validated by a confirmatory factor analysis (Carmeli et al., 2009). We added one additional item to the Psychological Safety construct in order to cover the perception of safety between the team and the facilitator.

This item was adapted from a study that aimed to measure key factors in collaboration and their relationship to teamwork satisfaction (Tseng et al., 2009).

Knowledge Creation. Three measures were used in this project to measure Knowledge Creation. The measures were adapted from the Knowledge Creation measures developed in a project by Choo et al., (2007) where they studied psychological effects on learning behaviours and knowledge creation. The original measures have previously been validated by a confirmatory factor analysis (Choo et al., 2007) and were scaled on a seven-point Likert scale from (1) 'Strongly disagree' to (7) 'Strongly agree'.

Engagement. The engagement construct consisted of four measures. Three of these were inspired by The Flow Proneness Questionnaire (SFPQ), which was developed in order to measure the proneness of psychological flow during a task performance. The measures were validated with a confirmatory factor analysis (Ullénet al., 2012). One additional item was developed to capture the excitement from a workshop (Hamari et $a l .$, 2016). All measures were evaluated on a five-point Likert scale from (1) 'Never' to (5) 'Always'.

Cohesion. Cohesion was developed as a construct in order to measure how united and collectively committed a team is. The construct consisted of three measures, all adapted from Carless and de Paola's (2000) use of the Group Environment

International Journal of Management and Applied Research, 2020, Vol. 7, No. 1 
Questionnaire (GEQ). The GEQ was originally developed to measure the cohesion within sports teams (Carron, Widmeyer and Brawley, 1985) but it has been adapted to many different settings such as measuring work teams (Carless and De Paola, 2000). The three measures were all developed for the purpose of assessing a group level performance during specific tasks. The measures were modified slightly for the purpose of this study. All measures were scaled on a seven-point Likert scale from (1) 'Strongly disagree' to (7) 'Strongly agree'.

Organizational readiness for change. Organizational readiness for change was measured using the Organizational Readiness for Implementing Change (ORIC) scale (Shea, Jacobs, Esserman, Bruce and Weiner, 2014). ORIC was developed to analyse how organizations are ready to implement new policies, programs and practices by measuring two constructs: Change Commitment and Change Efficacy. ORIC has been successfully validated by both exploratory and confirmatory factor analysis (Shea et al., 2014). The Change Commitment sub-scale consists of four measures that were adapted for the purpose of this study. Change Efficacy consists of five measures where three measures plus a self-developed item were adapted for the purpose of the study. The measures in the Change Efficacy do not cover the perception of receiving support in the change, which has been shown to be related to an improved individual readiness for change (Gigliotti et al., 2019). Thus, we self-developed one item for the purpose of capturing the perception of receiving support. The two Change Efficacy measures that were omitted were not highly related to outcomes from LSP workshops.

Table5 displays all original measures and the modified measures used in this research project.

Table 5: Original items, adapted items, references and Standardized Beta Values of the CFA

\begin{tabular}{|c|c|c|c|}
\hline $\begin{array}{l}\text { Original Indicators of } \\
\text { Motivation }\end{array}$ & $\begin{array}{l}\text { Adapted Indicators of } \\
\text { Motivation }\end{array}$ & Literature support & Loading \\
\hline $\begin{array}{l}\text { 1. I believe that this } \\
\text { activity is important } \\
\text { for me }\end{array}$ & $\begin{array}{l}\text { I participated in the } \\
\text { workshop because I } \\
\text { believe that the activity } \\
\text { was important for me } \\
\text { (Identified regulation) }\end{array}$ & $\begin{array}{l}\text { Burton et al., } \\
(2006) ; \text { Guay et al., } \\
(2000) ; \\
\text { Deciand Ryan } \\
(2000) ; \\
\text { Vallerand (1997) }\end{array}$ & $\beta=.72 * * *$ \\
\hline $\begin{array}{l}\text { 2. This activity was } \\
\text { fun }\end{array}$ & $\begin{array}{l}\text { I participated in the } \\
\text { workshop because the } \\
\text { activity was fun } \\
\text { (Intrinsic motivation) }\end{array}$ & $\begin{array}{l}\text { Guay et al., (2000); } \\
\text { Vallerand (1997) }\end{array}$ & $\beta=.66^{* * *}$ \\
\hline $\begin{array}{l}\text { 3. I do this activity, } \\
\text { but I am not sure if } \\
\text { it is worth it }\end{array}$ & $\begin{array}{l}\text { I participated in the } \\
\text { workshop, but I am not } \\
\text { sure it was worth my } \\
\text { while (Amotivation) }\end{array}$ & $\begin{array}{l}\text { Deci and Ryan } \\
(1985) ; \\
\text { Guay et al., (2000); } \\
\text { Vallerand (1997) }\end{array}$ & $\beta=.36^{* * *}$ \\
\hline $\begin{array}{l}\text { 4. I don't have any } \\
\text { choice }\end{array}$ & $\begin{array}{l}\text { I participated in the } \\
\text { workshop because I } \\
\text { didn't have any choice } \\
\text { (External Regulation) }\end{array}$ & $\begin{array}{l}\text { Deci and Ryan } \\
(1985) ; \\
\text { Guay et al., (2000); } \\
\text { Ryan and Deci } \\
(2000) ; \\
\text { Vallerand (1997) }\end{array}$ & $\beta=.37 * * *$ \\
\hline
\end{tabular}

International Journal of Management and Applied Research, 2020, Vol. 7, No. 1 


\begin{tabular}{|c|c|c|c|}
\hline $\begin{array}{l}\text { Original Indicators of } \\
\text { Psychological Safety }\end{array}$ & $\begin{array}{l}\text { Adapted Indicators of } \\
\text { Psychological Safety }\end{array}$ & & \\
\hline $\begin{array}{l}\text { 5. In working with } \\
\text { members of this } \\
\text { team, my unique } \\
\text { skills and talents are } \\
\text { valued and utilized }\end{array}$ & $\begin{array}{l}\text { My unique skills and } \\
\text { talents were valued and } \\
\text { utilized }\end{array}$ & $\begin{array}{l}\text { Carmeli, et al. } \\
\text { (2009); } \\
\text { Edmondson (1999; } \\
\text { 1996); } \\
\text { Edmondson and Lei } \\
\text { (2014) }\end{array}$ & $\beta=.80^{* * *}$ \\
\hline $\begin{array}{l}\text { 6. Members of this } \\
\text { team are able to } \\
\text { bring up problems } \\
\text { and tough issues }\end{array}$ & $\begin{array}{l}\text { You were able to bring } \\
\text { up problems and tough } \\
\text { issues }\end{array}$ & $\begin{array}{l}\text { Carmeli et al., } \\
(2009) ; \\
\text { Edmondson } \\
1996) ; \\
\text { Edmondson and Lei } \\
(2014)\end{array}$ & $\beta=.79 * * *$ \\
\hline $\begin{array}{l}\text { 7. It is safe to take a } \\
\text { risk on this team }\end{array}$ & $\begin{array}{l}\text { It was safe for me to } \\
\text { take a risk }\end{array}$ & $\begin{array}{l}\text { Carmeli et al., } \\
(2009) ; \\
\text { Edmondson } \\
1996) ; \\
\text { Edmondson and Lei } \\
(2014)\end{array}$ & $\beta=.73 * * *$ \\
\hline $\begin{array}{l}\text { 8. If you make a } \\
\text { mistake on this } \\
\text { team, it is often held } \\
\text { against you }\end{array}$ & $\begin{array}{l}\text { If you made a non- } \\
\text { conventional } \\
\text { suggestion, it was held } \\
\text { against you }\end{array}$ & $\begin{array}{l}\text { Carmeli et al., } \\
(2009) ; \\
\text { Edmondson (1999; } \\
\text { 1996); } \\
\text { Edmondson and Lei } \\
(2014)\end{array}$ & Omitted \\
\hline $\begin{array}{l}\text { 9. [No } \quad \text { original } \\
\text { measure; added by } \\
\text { us] }\end{array}$ & $\begin{array}{l}\text { The facilitator helped } \\
\text { create a secure } \\
\text { environment }\end{array}$ & Tseng et al., 2009 & $\beta=.65^{* * *}$ \\
\hline \multicolumn{4}{|c|}{$\begin{array}{l}\text { Original Indicators of } \begin{array}{l}\text { Adapted Indicators of } \\
\text { Group Cohesion }\end{array} \text { Group Cohesion }\end{array}$} \\
\hline $\begin{array}{l}\text { 10. Our team is united } \\
\text { in trying to reach its } \\
\text { goal for } \\
\text { performance }\end{array}$ & $\begin{array}{l}\text { Our team was united in } \\
\text { trying to reach the goal }\end{array}$ & $\begin{array}{l}\text { Carless and De } \\
\text { Paola (2000); } \\
\text { Carron et al. (1985); } \\
\text { Festinger (1950); } \\
\text { Mullen and Copper } \\
(1994)\end{array}$ & $\beta=.89 * * *$ \\
\hline $\begin{array}{l}\text { 11. I'm unhappy with } \\
\text { my team's level of } \\
\text { commitment to the } \\
\text { task }\end{array}$ & $\begin{array}{l}\text { Our team was } \\
\text { committed to the task }\end{array}$ & $\begin{array}{l}\text { Carless and De } \\
\text { Paola (2000); } \\
\text { Carron et al., (1985) } \\
\text { Festinger (1950) }\end{array}$ & $\beta=.87 * * *$ \\
\hline $\begin{array}{l}\text { 12. Our team members } \\
\text { have conflicting } \\
\text { aspirations for the } \\
\text { team's performance }\end{array}$ & $\begin{array}{l}\text { Our team members had } \\
\text { conflicted aspirations }\end{array}$ & $\begin{array}{l}\text { Carless and De } \\
\text { Paola (2000); } \\
\text { Carron et al., (1985) } \\
\text { Festinger (1950); } \\
\text { Mullen and Copper } \\
(1994)\end{array}$ & Omitted \\
\hline
\end{tabular}

International Journal of Management and Applied Research, 2020, Vol. 7, No. 1 


\begin{tabular}{|c|c|c|c|}
\hline $\begin{array}{l}\text { Original Indicators of } \\
\text { Knowledge Creation }\end{array}$ & $\begin{array}{l}\text { Adapted Indicators of } \\
\text { Knowledge Creation }\end{array}$ & & \\
\hline $\begin{array}{l}\text { 13. This team generated } \\
\text { many ideas while } \\
\text { doing the project }\end{array}$ & I generated many ideas & $\begin{array}{l}\text { Choo et al., (2007); } \\
\text { Healey et al.,(2015) }\end{array}$ & $\beta=.80 * * *$ \\
\hline $\begin{array}{l}\text { 14. Solutions found in } \\
\text { doing this project } \\
\text { were clearly unique } \\
\text { and innovative to } \\
\text { the company }\end{array}$ & $\begin{array}{l}\text { I found solutions that } \\
\text { emerged to be clearly } \\
\text { innovative }\end{array}$ & $\begin{array}{l}\text { Choo et al., (2007); } \\
\text { Nickerson and } \\
\text { Zenger (2004) }\end{array}$ & $\beta=.81 * * *$ \\
\hline $\begin{array}{l}\text { 15. Doing this project } \\
\text { enhanced the team's } \\
\text { ability and } \\
\text { knowledge to } \\
\text { perform future work }\end{array}$ & $\begin{array}{l}\text { I increased my ability to } \\
\text { do a better job }\end{array}$ & $\begin{array}{lr}\text { Choo et al. } & \text { (2007); } \\
\text { Grant }(1996) \text {; Healy } \\
\text { et al. (2015) } \\
\text { Nickerson } \\
\text { Zenger (2004) }\end{array}$ & $\beta=.80 * * *$ \\
\hline $\begin{array}{l}\text { Original Indicators of } \\
\text { Engagement }\end{array}$ & $\begin{array}{l}\text { Adapted Indicators of } \\
\text { Engagement }\end{array}$ & & \\
\hline 16. Self-developed & You got excited & $\begin{array}{l}\text { Csikszentmihalyi } \\
\text { (1990);Garfield, } \\
\text { (1987); Marottoet } \\
\text { al., (2007); Privette } \\
\text { et al., (1996); } \\
\text { Thornton } \text { et al., } \\
(1999)\end{array}$ & $\beta=.75^{* * *}$ \\
\hline $\begin{array}{l}\text { 17. You have a clear } \\
\text { picture of what you } \\
\text { want to achieve, and } \\
\text { what you need to do } \\
\text { to get there }\end{array}$ & $\begin{array}{l}\text { You developed a clear } \\
\text { picture of what you } \\
\text { want to achieve }\end{array}$ & $\begin{array}{l}\text { Csikszentmihalyi } \\
\text { (1990); Garfield, } \\
\text { (1987); Marottoet } \\
\text { al., (2007); Privette } \\
\text { et al., (1996); } \\
\text { Thornton et al., } \\
\text { (1999) }\end{array}$ & $\beta=.75^{* * *}$ \\
\hline $\begin{array}{l}\text { 18. You feel completely } \\
\text { concentrated }\end{array}$ & $\begin{array}{l}\text { You felt completely } \\
\text { concentrated }\end{array}$ & $\begin{array}{l}\text { Csikszentmihalyi } \\
\text { (1990);Garfield, } \\
\text { (1987); Marottoet } \\
\text { al., (2007); Privette } \\
\text { et al., (1996); } \\
\text { Thornton } \text { et al., } \\
\text { (1999) }\end{array}$ & $\beta=.65^{* * *}$ \\
\hline $\begin{array}{l}\text { 19. What you do feels } \\
\text { extremely enjoyable } \\
\text { to do }\end{array}$ & $\begin{array}{l}\text { You found the } \\
\text { workshop extremely } \\
\text { enjoyable }\end{array}$ & $\begin{array}{l}\text { Csikszentmihalyi } \\
\text { (1990); Garfield, } \\
\text { (1987); Marottoet } \\
\text { al., (2007); Privette } \\
\text { et al., (1996); } \\
\text { Thornton } \text { et al., } \\
\text { (1999) }\end{array}$ & $\beta=.75^{* * *}$ \\
\hline $\begin{array}{l}\text { Original Indicators of } \\
\text { Change Commitment }\end{array}$ & $\begin{array}{l}\text { Adapted Indicators o } \\
\text { Change Commitment }\end{array}$ & & \\
\hline
\end{tabular}

International Journal of Management and Applied Research, 2020, Vol. 7, No. 1 


\begin{tabular}{|c|c|c|c|}
\hline $\begin{array}{l}\text { 20. People who work } \\
\text { here are committed } \\
\text { to implement this } \\
\text { change }\end{array}$ & $\begin{array}{l}\text { I was committed to } \\
\text { implement relevant } \\
\text { changes }\end{array}$ & $\begin{array}{l}\text { Shea } \text { et al., (2014); } \\
\text { Roos and Said, } \\
(2005)\end{array}$ & $\beta=.80 * * *$ \\
\hline $\begin{array}{l}\text { 21. People who work } \\
\text { here are determined } \\
\text { to implement this } \\
\text { change }\end{array}$ & $\begin{array}{l}\text { I was determined to } \\
\text { implement this change }\end{array}$ & $\begin{array}{l}\text { Shea et al., (2014); } \\
\text { Roos and Said, } \\
(2005)\end{array}$ & $\beta=.80 * * *$ \\
\hline $\begin{array}{l}\text { 22. People who work } \\
\text { here are motivated } \\
\text { to implement this } \\
\text { change }\end{array}$ & $\begin{array}{l}\text { I was motivated to } \\
\text { implement this change }\end{array}$ & Shea et al., (2014) & $\beta=.81 * * *$ \\
\hline $\begin{array}{l}\text { 23. People who work } \\
\text { here want to } \\
\text { implement } \\
\text { change }\end{array}$ & $\begin{array}{l}\text { I wanted to implement } \\
\text { this change }\end{array}$ & Shea et al., (2014) & $\beta=.83^{* * *}$ \\
\hline $\begin{array}{c}\text { Original Indicators of } \\
\text { Change Efficacy }\end{array}$ & $\begin{array}{l}\text { Adapted Indicators of } \\
\text { Change Efficacy }\end{array}$ & & \\
\hline $\begin{array}{l}\text { 24. People who work } \\
\text { here feel confident } \\
\text { that they can } \\
\text { coordinate tasks so } \\
\text { that implementation } \\
\text { goes smoothly }\end{array}$ & $\begin{array}{l}\text { I was convinced I could } \\
\text { coordinate tasks to } \\
\text { smooth } \\
\text { implementation }\end{array}$ & Shea et al., (2014) & $\beta=.77 * * *$ \\
\hline $\begin{array}{l}\text { 25. People who work } \\
\text { here feel confident } \\
\text { that the organization } \\
\text { can support people } \\
\text { as they adjust to this } \\
\text { change }\end{array}$ & $\begin{array}{l}\text { I was convinced I could } \\
\text { support people as they } \\
\text { adjust to changes }\end{array}$ & Shea et al., (2014) & $\beta=.82$ \\
\hline $\begin{array}{l}\text { 26. People who work } \\
\text { here feel confident } \\
\text { that they can handle } \\
\text { the challenges that } \\
\text { might arise in } \\
\text { implement this } \\
\text { change }\end{array}$ & $\begin{array}{l}\text { I was convinced I could } \\
\text { handle the challenges } \\
\text { that may arise during } \\
\text { implementation of the } \\
\text { changes }\end{array}$ & Shea et al., (2014) & $\beta=.76^{* * *}$ \\
\hline 27. Self-developed & $\begin{array}{l}\text { I was convinced I } \\
\text { would be supported in } \\
\text { this change }\end{array}$ & $\begin{array}{l}\text { Gigliotti et al., } \\
(2019)\end{array}$ & $\beta=.73 * * *$ \\
\hline
\end{tabular}

International Journal of Management and Applied Research, 2020, Vol. 7, No. 1 